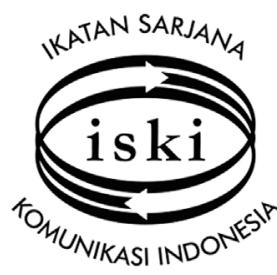

\section{Flip and Switch - Minority and Cult Film in Indonesian Cinema}

\author{
Ahmad Riza Faizal \\ Department of Communication, Lampung University \\ Jl. Sumantri Brojonegoro No. 01, Rajabasa, Lampung 35141 - Indonesia \\ ahmad.riza@fisip.unila.ac.id
}

\author{
I S K I
}

\begin{abstract}
This research has put forward the Flip and Switch concepts as milestones for signifying when a film narrative change their syntagmatic course through characters back and forth in weight and position thus change the messages that might be conveyed by the spectators about the film. The concepts were pointed by using the semiotic rectangle, or also known as The Greimas' rectangle, about minority issues in one of the best Indonesian film ever made, Cahaya dari Timur: Beta Maluku. This research found two flips and two switches which signify changes in course and narrative patterns through out the film. By using criterion of what makes a film become a cult film, the research sorted and opted several peculiar scenes. Those scenes can leads the film become a cult film if the phenomena criteria are lifted and established over time. Nevertheless, at present, the film Cahaya dari Timur: Beta Maluku is not yet a cult film. Related to minority issues, the film comes from a non Anti-minority issues which complements with antiminority issues, these findings signified that Cahaya dari Timur: Beta Maluku is not a film about minority issues but what has became after all those minority conflicts are solved.
\end{abstract}

Keywords: Semiotic Film, Minority, Cult Film

\begin{abstract}
Abstrak
Penelitian ini mengajukan konsep flip dan switch sebagai penanda mengenai pertukaran bobot dan kedudukan karakter dalam film dengan menganalisa menggunakan metode logika segi empat semiotika (The Greimas' Rectangle). Temuan dari penelitian ini dalam film Cahaya dari Timur: Beta Maluku terdapat dua flips dan dua switches yang menandakan perubahan dalam sudut pandang dan pola naratif yang hendak disampaikan oleh film terhadap harapan jalan cerita yang ada dibenak penonton. Dengan mengambil kriteria-kriteria yang dapat menjadikan sebuah film menjadi cult film, temuan penelitian ini memilah dan memilih adagan-adegan kekhasan. Adegan-adegan kekhasan tersebut dapat mengarahkan film ini menjadi cult film jika seiring waktu terbentuk fenomena-fenomena yang dapat mengangkatnya. Tetapi pada saat ini, film Cahaya dari Timur: Beta Maluku bukanlah sebuah cult film. Dari sebaran isu diketahui bahwa film Cahaya dari Timur: Beta Maluku berangkat dari ide mengenai non anti-minoritas yang berkomplemen terhadap kedudukan isu anti-minoritas. Temuan ini menandakan bahwa film ini bukanlah film mengenai minoritas tetapi apa yang lahir setelah konflik minoritas diselesaikan.
\end{abstract}

Kata Kunci: Semiotika Film, Minoritas, Cult Film 


\section{Introduction}

Film, as known as cinema, is one of modern mass media that has a fair fanatic of the audience with specific character and it has been proved to be an effective media when it comes to the dissemination of an issue. In Indonesia, the condition is not different, there are many films that proved to be successful when they are issues disseminated. One of the films that arises minority issues is Cahaya dari Timur: Beta Maluku. The film won the movie of the year award at the Indonesian Film Festival 2014-- the most prestigious film festival in the country. Furthermore, the Tempo magazine, one of the leading news magazines with millions of readers in Indonesia, also put this film as the best film in 2014. At the same year, there were also many films, even at the same genre in sport film, had been produced and also had stand out expectations from the audience back then, like Garuda di Dadaku, Hari ini Pasti Menang, Garuda 19, and Tendangan dari Langit. Nonetheless, among those aforementioned films, there was no single film that explored an issue on minority as well as Cahaya dari Timur: Beta Maluku.

Hopkins (2008: 149) proposed a film consisting at least two level of representations in which the audience must take into account to reveal meanings of the film brought them up. At the first level, there are actors, properties, sets, and film impacts who or which can tell us a specific narrative as so-called the story told. In the next level, all the first level components are blended and arranged in a more complex orchestra to produce a layer-by-layer photographic records as so-called the events filmed. Representation, as Hopkins (2008: 151) pointed, has an ability to capture what in the audience's mind if, whatsoever, those two levels managed to combine and work in harmonious and transparent way. Speaking on transparency side of the film narrative, Wilson (2008: 81) coincided that as the basic foundation for audience to allegedly say their subjective visual experience has became their own objective consciousness. Wilson also (2008: 8182) referred the narrative concept, as a term of "twist" in a film whenever the audience feel the story course they judge as a plot in the beginning of the film and all of sudden, the audience became to reverse to their own understanding, like a betrayal to their own prediction, leading to a different "prognostic" about the narrative after watching the film. The twist however, appears not only within the plot but also relates to the overall messages the film carries (Wilson 2008:
81), and maybe more than twice in a single plot. What makes the concept really reflect a narrative transparency of the film because in fact it is easy for the audience to recognize the film configuration and representation.

Representations has its own special place in visual communication; technically, visual communication sees all scenes in a film as "text" assembled from plot and narrative (Kress et., al. 2006: 17) and threaded in a unique construction to form a familiar comprehension and logic, known as "langue", -- language. Thus, language is the human's media in which is naturally understandable as a part of the human's existence itself. The research problems were defined as; how does film semiotics signify the minority issue in Indonesian cinema? At a certain level, whether the film has managed to gain many spectators and fandoms, and a particular unique position within the perspective of local people that make the film to be a cult film. The purpose of this research was to discover the dissemination of minority meanings in Indonesian cinema by analyzing the film Cahaya dari Timur: Beta Maluku. Thus the signification expected from this research was to enlighten and enrich film as media studies in Indonesia, particularly for the forthcoming research using film semiotic as their method.

\section{Theoretical Framework}

Phillipe Le Guern (2004) referred the usage of 'cult' on television series, films, novels, and music which had been praised in such a way as groups of fan, and in some aspects, symbolized values, social status and sub-culture of themselves. Nonetheless, he also mentioned contemporary usage of the word on more religious practice which brought an ambiguity and made many attempts at the definition and delimitation of the concept and its more difficult usage. However, the difficulties' that Le Guern mentioned, have derived from two causes-- First, subordinate disposition by sociology approach in social environment and an inability to reflect the meanings of its own practice. Second, it concerns on analogy of media cults and religious cults. He noted Walter Benjamin thoughts about the idea of an art, such as cinema, could only exist on reproduction level (as opposed to unique reproduction) in which it reproduced invalidates of 'cult value' of art. Therefore, Le Guern proposed a question whether the concept of 'Cult' should be reduced from a nominalist perspective to the product of linguistic game, to one of those classi- 
fication schemes that was created by the observer but devoid of reality. He argued this sublimation of film, generally speaking, as functioned unifier which produced groups and spectators, by its expression of attributed values, thus maintained their enthusiasm for the cult text. In spite of cult film as reducible text, Le Guern emphasized the role of, in his term, 'participatory culture' of fans, communities, and by rituals as a social construction of cults. This niche distinguished the authentic/original cults and inauthentic/planned cults based on historical concept of which the point of transitions were rationalization and exploitation tastes in order to be understood; these tastes have occurred in the procession of successive generations and in their cultural practices and conditions, and context of these practices as well.

The fandom, however, had attracted Hills (2002) who bear the relation between fandom and cult culture in academic perspective. He argued that it was actually not an easy task to define fandom itself because of the 'everydayness' term. Nowadays everyone knows what a ' $f a n$ ' is. Of course, Hills took Abercrombie and Longhurst (1998) attempt by linking the concept of ' fan', 'cultist', and 'enthusiast'. He also mentioned Tulloch and Jenkins (1995) were less contradictory in their definition, despite the term 'cult', of 'fan' and 'followers'. Nonetheless, he realized that the concept of 'fandom' and 'cult fandom' sometimes overlapped. 'Cult fandom' is more likely implied cultural identity which is part of the concept of ' $f a n$ ' in general. Thus, he suggested that this duality was not related not to the intensity, social organization or semiotic/material productivity of the fandom concerned, but rather than to its duration, notably in the absence of 'new' or official material in the medium originating. Indeed, how those dimensions above arise, it involved subjectivity from sub-culture in that cult fans belong to which, according to Christian Metz thoughts, was derived from process of identification, voyeurism, and fetishistic. This perception, despite of the 'product' of cult itself and geographical means, whatsoever, came up as collective conscious that is claimed to be the institution through symbolization process with the 'cult" term presenting as a label. In other words, inter subjectivity with society, particularly in culture where the fans belong to, makes a film being adored. Thus, cult film cannot be separated from cult fandom because fandom makes film 'cults' vice versa. However, the process within film and its fandom is not as disputed or overlapped as Le Guern and Hills proposed, in my perspective; nevertheless semiotic can clearly distinguish among those labels.

\section{Material and Methodology}

Film semiotic as a method, was influenced by the works of three distinguished scholars; Christian Metz, Juri Lotman, and Roland Barthes. The main question should be asked whenever one attempts to apply semiotic as an interpretation method for film, whether the film has any signification (how does the film signify?) in the sense as the signifier media. In spite of the massage the film conveyed are spoken through conventional signs of, in Metz's own word, the film's language. Nonetheless, it would be a challenge for film semiotic to unmask such claimed significations, like "there" (exist) and "true". In a more general context, Danesi (2002: 122-128) had a disagreement with Metz on how film been treated almost like has a similar structural influenced as the natural human's language. In his opinion, it is a more accurate to be said that film is a syntagmatic text with a broad categories made by language. Those categories are filled with a configuration of dialogs, music, scenes, and role plays in more cohesive way. Film, more precisely, is a media combined of verbal and non-verbal significations.

Rose (2007: 87, also Kress, et al. 2006: 114) mentioned that ideology also has a prominent role to show how significant the signs can be. Rose, based her point of view on Williamson (1978 in Rose 2007: 87) and Barthes (1973, in Rose 2007: 87) notions of any structural segregation on metaphorical sign that leads to metonymic and synecdoche, a figure of speech in which a part is made to represent the whole or vice versa (sign is either a part of something standing in for a whole, or a whole representing a part). Moreover, Kress (at., al. 2006: 47) agreed with Metz in regard with visual structuring of sign. For him, the visual structuring has been treated more as a reproduction of structural reality, instead of the creation of proposition, filled with arbitrary meanings by comprehend visual syntax or merely any formal language. On one hand, visual structure simply just produced a literal reality, on the other hand, produced reality also created an imaginary reality that bounded with social institution's interest where the imagination was created, disseminated, or just merely read from. Visual structure has never been recognized before in formal sense since they had a very deep symantical dimension. 


\section{The Greimas' Rectangle}

Algirdas Julien Greimas, a linguist and semiotician from Lithuania, designed a particular method and logic to interprete ideas within narrative text and mapped the structure of significations based on Aristotle's logic of opposition method (Aristotle's square of opposition). The method was widely known as 'the semiotic square' or 'the Gremais' rectangle' (KatiliusBoydstun, 1990). Katilius-Boydstun (1990) reffered the method as a comprehension on how to articulate a symantic structure from significations within the binary opposition structure of text. Based on Greimas' work, Katilius-Boydstun (1990) pinpointed the opposition's logic to be more beneficial rather than a conventional logic of contradiction or of duality (binary) in terms of signification production. Such condition has met as the logical method combined three type of sign relations which consist of -- contradiction, opposition, and complementary. Greimas also designed the method more credible with four propositons instead of three propositions in Hegelian's dialectical logic (thesis, anti-thesis, synthesis). The fourth proposition is called, borrowing from $\mathrm{He}$ gelian's term, negation of negation. Such proposition gave the semiotic square method an ability to bear a novel proposition sequence thus levitate the comprehension gained from a narrative text to an entire new level.

The Greimas' rectangle method consists of double opposition and negation concepts based on $\mathrm{He}$ gelian's dialectical terms, thesis and anti-thesis. The relations are:

$\mathrm{S} 1$ and S2

: Oposition

S1 and $\sim$ S1, S2 and $\sim \mathrm{S} 2$ : Contradiction

S1 and $\sim$ S2, S2 and $\sim S 1$ : Complementary

The method also bear on metaconcepts are:

S1 and S2 (universal)

not S1 nor S2 (non-universal)

Strauss \& Corbin (1998: 3) saw methodology as a way of thought for researcher when they are approaching and studying about social reality. This research used qualitative approach that has integrated the researcher as the participant and instrument research at the same time. The research also combined secondary data collection and semiotic as the analysis tools and developed the comprehensions based on findings. Firstly, data were collected by using direct observation to the research object and supporting documents to validate the findings, in this stage re-
Figure 1

The Greimas' rectangle

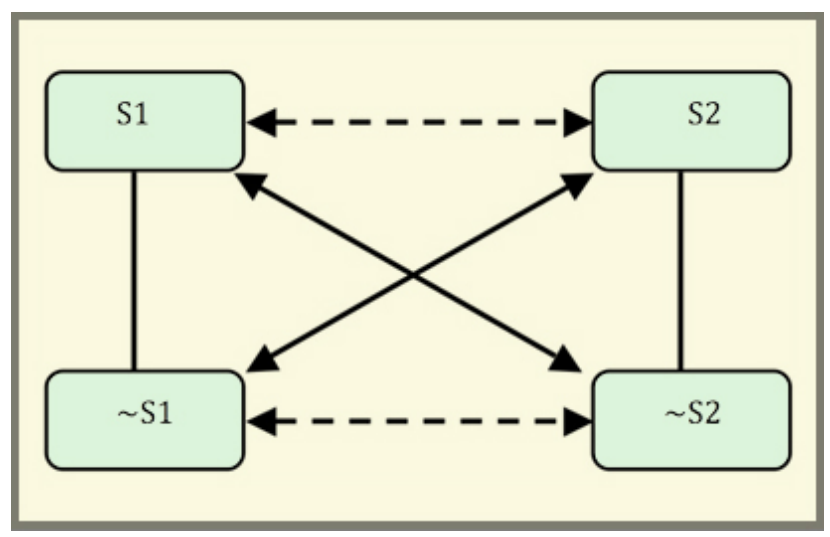

searcher watched and re-watched the film to map all the significations that were recognized. Secondly, the collected data being analyzed by using the Greimas' rectangle method to discover the dissemination of minority issues based on scenes observed, each noted that scenes were placed in accord to the relevant proposition. Lastly, all the findings were discussed based on cult film theory and its relevancy. Since the research was in the subjective research domain, therefore obstacles were found during the research conducted mostly on the availability of secondary supporting data and cross-references.

\section{Result and Discussion}

The film, Cahaya dari Timur: Beta Maluku premiered on June $19^{\text {th }}, 2014$. This drama film was based on actual non-fiction story of Sani Tawainela, a former football player from Tulehu, Maluku province. After having failed his endeavor to become a national player, Sani decided to retire and return to his home village, Tulehu. While working as Ojek (motorcyletaxi) driver, Sani saw how children and teenagers suffered from religious conflicts in his town and determined to help them by redirecting their negative energy for something positive such as playing football; then Sani built a football school. After ups and downs as well as breaking up with his old friend regarding their city football teams, Sani was pointed to be the head coach of Maluku's football team and sent to the capital city, Jakarta, for leading the team at the national football competition. The challenge began with his decision to incorporated team members with different backgrounds, which might lead to discord. (Cahaya dari Timur: Beta Maluku, 2016).

Umberto Eco argued (1986: 197) intertextual- 
Table 1

Significations noted from the film Cahaya dari Timur: Beta Maluku

\begin{tabular}{|c|c|}
\hline Time & Observed List \\
\hline$(03: 27)$ & $\begin{array}{l}\text { A man rushing to a power pole on the side of a narrow street and hit it loudly in fast rhythm, all of sudden every- } \\
\text { one who heard the sound became panic and scattered. }\end{array}$ \\
\hline$(04: 36)$ & $\begin{array}{l}\text { Three young men called Sani and asked him to join them at district border because there was a fight between the } \\
\text { warring parties. No visual on hitting the power pole like the previous scene, there was a faint sound of people hit } \\
\text { a power pole though. }\end{array}$ \\
\hline (09:52) & $\begin{array}{l}\text { The sound of power poles hit loudly. Everyone who was practicing football became panic and rushed over to the } \\
\text { source of the sound. }\end{array}$ \\
\hline$(10: 20)$ & $\begin{array}{l}\text { People carried weapons running towards the sound of power poles was hit. The sound became synecdoche of } \\
\text { fight. }\end{array}$ \\
\hline$(21: 37)$ & $\begin{array}{l}\text { A man hit the power pole by using a stone. Everybody around him ran away and scattered. The atmosphere was } \\
\text { described as tense and panic. }\end{array}$ \\
\hline$(56: 50)$ & $\begin{array}{l}\text { Yosef of Passo High School, with his official state uniform asked Sani to train a football team in his school, with- } \\
\text { in Christian district. The narrative was reversed by plotting Sani as if he "crossed" to the other side. Researcher } \\
\text { marked it as Flip-1. }\end{array}$ \\
\hline$(57: 50)$ & $\begin{array}{l}\text { Yosef was scolded by the Head of Passo High School for allowing Sani train their football team, whereas Yosef } \\
\text { knew that Sani was a muslim. "What the parents will say if they find out that Sani was coaching here?"The char- } \\
\text { acter's weight of Sani changed from being a dominant in Tulehu to a minority in Passo. Researcher marked it as } \\
\text { Switch-1. }\end{array}$ \\
\hline$(58: 35)$ & $\begin{array}{l}\text { Yosef argued to the principal that by allowing Sani coach in their school, it would show to the society that the } \\
\text { school gives a good example on reconciliation between muslims and christians after the conflict. }\end{array}$ \\
\hline$(1: 06: 30)$ & Two kids from Tulehu were allowed to join Passa's football team under supervision from Sani. \\
\hline$(1: 10: 40)$ & The football match between Tulehu Putra and SMK Passo won by Tulehu Putra. \\
\hline$(1: 18: 09)$ & $\begin{array}{l}\text { In a practice session, Salembe, a player from Tulehu did a tackling to a player from Passo. He did that because Sa- } \\
\text { lembe knew the player's father was the police commander back when the conflict happened and Salembe's father } \\
\text { was shot by the police in one of the brawls. Domination, almost like bullying, and resistance feelings condensed in } \\
\text { this scene, especially when the player who was tackled did not do anything, just like a victim. Researcher marked } \\
\text { it as Switch-2. }\end{array}$ \\
\hline$(1: 35: 00)$ & $\begin{array}{l}\text { Maluku's team was defeated by Jakarta team, quarrel appeared between two teams on the field. During break } \\
\text { time, Maluku's team also had quarrel among themselves in the locker room. }\end{array}$ \\
\hline$(1: 36: 20)$ & $\begin{array}{l}\text { One of Maluku's team player hit a DKI's player because he did not accept their lost in the first match. Domination } \\
\text { role was obviously settled by fights, the scenes showed how such role being back and forth between those team } \\
\text { was. }\end{array}$ \\
\hline$(1: 46: 50)$ & $\begin{array}{l}\text { Sani wrote the word "Maluku" on a board. Sani brought the players to realize, at the moment there was no Tulehu, } \\
\text { Passo, Muslims nor christians, there was only Maluku's players, against others player, conflicts only result weakness } \\
\text { and weakness will make them defeated. High cohessivity described by high spirit backsound and emotional faces. } \\
\text { Researcher marked it as Flip-2. }\end{array}$ \\
\hline$(1: 57: 00)$ & $\begin{array}{l}\text { Maluku's team made the score even 1-1 against Jakarta's team on the final round. When the even goal happened } \\
\text { the film visualized simultaneously some scenes where everyone who watched the match, all of sudden rising up } \\
\text { or even jumping around and cheering each other. The goal was signified as a sign of joy and happiness. }\end{array}$ \\
\hline
\end{tabular}


ity comes from our own encyclopedia of textuality. Nonetheless, one have to created their own frame of reference, the knowledge comes from experiencing reality, before having identified which text of film has shown signification. The references are prominent for supporting the audience how to distinguish and select the intertextuality from general text. After having watched the film Cahaya dari Timur: Beta Maluku repeatedly, the researcher began to select which scenes have the strong signification thus they can distinguish the scenes itself as their own intertextuality idea. Afterwards, the scenes are noted with respective description about intertextuality in which the scenes related into. The notes are arranged in chronological and time order (numbers shows hour: minute: second in film duration) as follows:

After having observed directly and repeatedly on the research object, researcher found two points marked as Flip. The scenes are; when Sani coaching the Passo's football team and when Sani motivated the Maluku's players on what the word "Maluku" meant for them. There is a change in narrative's course and the way the story is told, -- does it alarm the audience. Such condition happened on how the syntagmatic prediction of conveyed meanings the audience had in mind that did not meet their expectation, and urged the sense to recognize what they expected to happen or at least became blur and unobvious. Researcher borrowed Barthes' concepts of obvious/obtuse meaning (1977)--nevertheless the descriptive aspects are implemented on the plot level, hence called it Flip. Flip is recognized as a peculiar scene that only belong to the particular film. One might called as a memorable and unique scene that changed the spectator opinion about a character or the entire film. Both flips aforementioned above belong to film $\mathrm{Ca}$ haya dari Timur: Beta Maluku, others will only follow it but the origins are from this film. The peculiar scenes purely come from the audience interpretations on Sani's own experience --one might have read or watched other news about Sani's life but this film had their own story and that narrative had been caught in the audience mind as an early expectations. Referred to the 'obvious meaning' from Barthes (1977), thus syntagmatic expectations of the audience were to replay to the condition after the flip happened. In this sense, those flips in this film are claimed to be milestones for the film narrative course, signified with the shifted expectations of communicants.

Other than certain conditions when the audi- ence expectations to the story told in the film flipped (changed), there was also signification that affects the characters weight, to the story, and angle from the audience point of view. The sign has affected not only in parts but also the entire narratives carried in the film, text and context. Such conditions are called Switch. Switch is the scenes that change the audience feel about how the film narrative (narrative = chronicle), from stereotypes to perspectives, managed plotted characters from beginning till ending, it sometimes goes to a discussion even after the audience leave the screen. A total sum of the audience's experience about the film Cahaya dari Timur: Beta Maluku, researcher has found two scenes marked as Switch. The first one was when Yosef was scolded by the Head by letting Sani coach their school football team. The second one was when Salembe tackled one of Passo player and the player did not fight back. Both scenes had their own affection to arise the audience's a certain feeling. Sympathy feeling came up when watching Yosef's empathy for Sani and a sense of vexation had collide the expectations on Salembe when he did the tackle and went rampage. Both senses were enriched and complemented, in an obtuse way, the interpretations expected from the audience about the whole narrative and syntagmatic meanings. Surprisingly, it is how the affections attracted to the audience's interest and recognition, and memorize it like an index for some particular films.

Flip and Switch are new terms that researcher proposes to make a substantial change of conveyed meanings within a story or film narrative and these terms taking their perspective from film as a communication process. Wilson (2006: 81-82) talked about 'transparency' in film which gives the spectators a feeling "to imagine seeing" on what are the meanings that characters or even the film plot going to be told. Such changes have affected expectation of the spectators, or in his term 'twisted', about how the story might end through technical actions called "impersonal subjectively inflicted shots". Taken such an idea from George Wilson nonetheless without being framed in technical film production, it is a subject in film studies but not the communication studies. Researcher thought that there should be milestones when a film put their remarkable works on how they managed to plant a particular impression and certain ideas in the spectators' mind through peculiar and unique scenes. A propaganda alerts without mentioning that it was propaganda. Thus the milestones 
would rise a more comprehensive understanding on how messages affected their meaning from the communicant point of view, despite of the communicator's intentions.

Referred to the concept of cult film, a film is being adored whenever the prominent phenomena consolidated and can be taken as their own outstanding proposition for the film to be exist and acceptable in the eyes of public institutions and public interests. The adoration manifested through, either a part or the entire film, was not just peculiar but also phenomenal scenes. From this research, researcher found that the film Cahaya Dari Timur: Beta Maluku had not have scenes yet that can be considered as "phenomenal", although two flips and two switches, as discussed above are worth to be marked as peculiar scenes belonging to this particular film only. Those scenes indeed had its own unique attractiveness, nonetheless they stand as its own intertextual idea and can be of memorable in the future-- researcher found that it still needs a lot of efforts to come. Cult film has never created in hasty though. It's only three years after its premiere, yet the film still needs to solicit its fandom through more rapid campaign and advertising. Still to early to say that the film was worth to be adored. Hills (2002: 2) pinpointed about the significant works of community of fans in regard to levitate and shine the film so it it worth as an accentuation in the society's mind, through festivals and awards. Jenkins (2006: 177) mentioned the role of limitless promotions and mass media usages (seamless promotion) and Eco (1986: 197), urged the works of people and professions who cited, copy, even put it into a parody of certain scenes of a film thus film Cahaya dari Timur: Beta Maluku had been not sighted, at least documented, worth --with such phenomena, therefore the researcher claimed that it is not to be a cult film yet.

From the dissemination of ideas observed, the minority issue was taken as the primary issue brought by the film narrative and reflected within representations of warring parties and its struggle through Sani's eyes. The marked flips and switches have reinforced the significations on what issue was being played back and forth in dialogs, the actor's expression and settings. Hence the minority issue places in its proposition in the Greimas' rectangle and bears the relations with other issues as follows:
Figure 2

Dissemination of issues in film Cahaya dari Timur: Beta Maluku

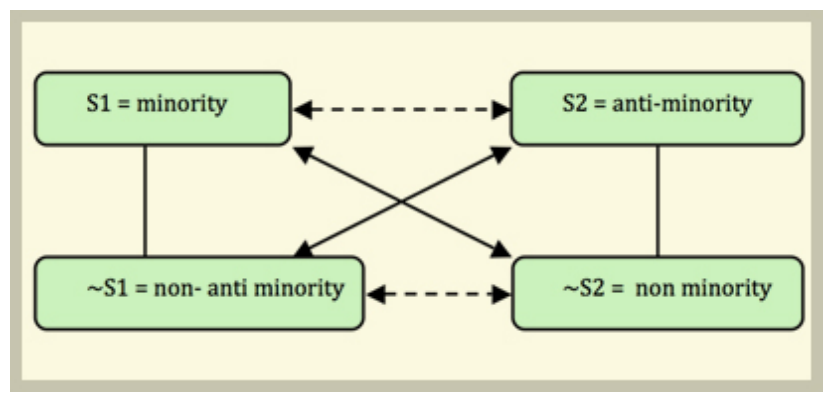

In film Cahaya dari Timur: Beta Maluku, minority issue has complemented with non-minority issue in spite of the audience's reason being carried away to comprehend such phenomena and the proposition bringing them to recognize that it was a consequence from the minority perspective in the film. In observed list number 7, 11, and 12, the minority issue has complemented with notions number 6,9 , and 14 . When the narrative had played its logic through the plot hence the audience's reason was formed. Observed list number $1,2,3,4,5$, and 13 have placed in nonanti-minority issue, making it to be a dominant and obvious issue about the film which was complemented with list number $8,10,12$, and 15 . Based on the semiotics square logic, the dominant issue appeared in most of the film comprehends as the main issue, Cahaya dari Timur: Beta Maluku was to stimulate the non-anti minority issue and precedents to its cause. Having represented scenes genuinely by describing the minority people position among conflicts within Ambon society at the moment, and the narrative urged to contradict with vigorous issues on how to muffle such an idea. With this spirit, thus the nonminority sentimental has become the anti-climax of the film narrative.

\section{Conclusion}

Film Cahaya dari Timur: Beta Maluku has two flips and two switches which signify changes on the narrative pattern and perspectives of the story to be told in the minds of audience. Those changes recognized through peculiar scenes that may lead the film to become a cult film if prominent phenomena has occurred and showed their vigorousness to levitate the film existence. However, at present, film Cahaya dari Timur: Beta Maluku has not yet a cult film.

Having looked at the dissemination of issues this film carried, a dominant idea of the non-anti-minor- 
ity issue has colored the most impression from the film, nonetheless the issue has also complemented harmoniously with anti-minority proposition. These results have showed that film Cahaya dari Timur: Beta Maluku is not a film about minority but what has become after all those minority conflicts are solved.

\section{References}

Barthes, R. 1977. Image-Music-Text.Fontana Press. London.

Barthes, R. 1982. A Barthes Reader. (S. Sontag, Ed.) Hill and Wang. New York.

Bignell, J. 1997. Media Semiotic: An Introduction.Manchester University Press. England.

Cahaya dari Timur: Beta Maluku. 2016. Film Indonesia. http://filmindonesia.or.id/movie/title/ lf-c02514-112311_cahaya-dari-timur-beta-maluku\#.V14sTuZ9634 downloaded June $8^{\text {th }}, 2016$.

Cahaya dari Timur: Beta Maluku Full Movies (Original). Uploaded January $24^{\text {th }}, 2015$.Youtube.https://www. youtube.com/watch? v=RTodW9w 1 mwdown loaded March 29 ${ }^{\text {th }}, 2016$.

Danesi, M. 2002. Understanding Media Semiotics. Arnold. London.

Eco, U. 1986. "Casablanca”: Cult Movies and Intertextual Collage. In Eco, U. Travels in Hyper Reality: Essays (p. 197). Harcourt Brace Jovanovich. New York.

Guern, P. 1. 2004.Towards A Constructivist Approach to Media Cults. In I S. G.-J. Pearson, Cult Television (s. 242).Univ. of Minnesota Press.Minnesota, US.
Hills, M. 2002.Fan Cultures. Routledge. England.

Hopkins, R. 2008. What Do We See In Film?.The Journal of Aesthetics and Art Criticism Vol. 66 No. 2-Spring 2008.The American Society for Aesthetics. Washington.

Jancovich, M. 2003. Defining Cult Movies: The Cultural Politics of Oppositional Taste.Manchester University Press. England.

Jenkins, H. 2006. Convergence Culture: Where Old and New Media Collide. NYU Press.US.

Katilius-Boydstun, M. 1990. The Semiotics of A. J. Greimas: an Introduction, Lituanus: LituanianQuaterly Journal of Arts and Sciences. Vol. 36 No. 3- Fall 1990. downloaded March 29 $9^{\text {th }}, 2016$ http://www.lituanus. org/1990_3/90_3_02.htm.

Kress, Gunther \& Theo van Leeuwen. 2006. Reading Images: The Grammar of Visual Design, Second Edition.Routledge. New York.

Pickard, Alison Jane. 2007. Research Methods in Information. Facet Publishing. London.

Rose, G. 2007. Visual Methodologies: An Introduction to Interpretation of Visual Materials, Second Edition. Sage Publications. London.

Strauss, A. L., \& Corbin, J. .1998. Basics of qualitative research: techniques and procedures for developing grounded theory (2nd Edition. utg.). Sage Publications. London.

Wilson, G. 2006. Transparency and Twist in Narrative Fiction Film. DalamThinking Through Cinema: Film as Philosophy. Blackwell Publishers. New York. 